\title{
Endometrial health and disease in the mare - Comparison of histopathological findings and microbiological results of two different culture methods: uterine swab and endometrial tissue
}

\author{
Sandra Schönigerl, Harald Sieme², Franziska Mönnig², Johanna Richter², Gunilla Martinsson³ , Jutta Verspohl'4, Heinz-Adolf Schoon' \\ ${ }^{1}$ Institute of Pathology, Faculty of Veterinary Medicine, University of Leipzig, Germany \\ ${ }^{2}$ Clinic for Horses - Unit for Reproductive Medicine, University of Veterinary Medicine Hannover, Foundation, Hannover, Germany \\ ${ }^{3}$ Celle National State Stud, Celle, Germany \\ ${ }^{4}$ Institute of Microbiology, University of Veterinary Medicine Hannover, Foundation, Hannover, Germany
}

\begin{abstract}
Summary
Endometritis is an important factor of subfertility in mares, commonly associated with a bacterial infection. In this study, endometrial swabs and biopsies of 41 mares were investigated with the objective to compare results of two different culture methods (swab culture with enrichment and biopsy culture) with the histopathological detection of endometritis. None of the mares showed clinical evidence of endometritis on gynecological examination. By histopathology, endometritis was diagnosed in 11 mares, it was mild in all mares, superficial in 9 mares, acute suppurative in 1 mare, subacute suppurative in 7 mares and non-suppurative in 3 mares. Identified facultative pathogens were betahemolytic Streptococci (11/41 mares; 27\%), Pseudomonas aeruginosa (1 mare) and hemolytic E. coli (1 mare). The swab culture with enrichment identified more frequently facultative pathogens (12 mares) than the swab culture prior to the enrichment or the biopsy culture, but resulted in the highest number of mixed cultures (51\%). Categories of culture results (A: likely apathogenic bacteria; B: ${ }^{3} 1$ facultative pathogen) showed a higher identity between biopsy culture and swab culture prior to the enrichment (93\%) than between biopsy culture and swab culture after enrichment (78\%). In regard to the 11 of 41 mares $(27 \%)$ with a histopathological diagnosis of endometritis, facultative pathogens were isolated from 5 mares. Beta-hemolytic Streptococci were detected in 6 mares without endometritis. In regard to the mare with the isolated hemolytic E. coli, a concise histopathological evaluation of the endometrial biopsy was precluded by the presence of artefact. This study showed that 1) bacterial culture results have to be evaluated under consideration of the applied methods, 2) an enrichment medium should be used to investigate the presence of facultative pathogenic bacteria, 3) bacteriological results should be interpreted together with the results of a complete histopathological examination (instead of an uterine cytology), since only the histopathological examination will reveal all subtypes of endometritis and 4) therefore a complete histopathological examination should be used as gold standard to diagnose endometritis. Thus, combined bacteriological and histopathological findings should be considered to decide on subsequent antibiotic treatment.
\end{abstract}

Keywords: endometrial biopsy / uterine cultures / endometritis / histopathology / mare / reproduction

Correspondence: Dr. Sandra Schöniger, Dipl. ACVP, Fachtierärztin für Pathologie, Instituł für Pathologie, Veterinärmedizinische Fakultät, Universität Leipzig, An den Tierkliniken 33, 04103 Leipzig, E-Mail: sandra.schoeniger@vetmed.uni-leipzig.de

Citation: Schöniger S., Sieme H., Mönnig F., Richter J, Martinsson G., Verspohl J., Schoon H.-A. (2014) Endometrial health and disease in the mare: Comparison of histopathological findings and microbiological results of two different culture methods (uterine swab and endometrial tissue). Pferdeheilkunde 30, 26-36

\section{Introduction}

Endometrial disease, including endometritis, is an important reason of decreased fertility and reduced breeding success in the mare; therefore it is of major economic importance for the horse breeding industry (Woolcock 1980, Causey 2006, LeBlanc and Causey 2009). Endometritis is often associated with a bacterial infection (Woolcock 1980, Causey 2006, LeBlanc and Causey 2009). In equine practice, it is commonly diagnosed by gynecological examination, exfoliative cytology and/or bacteriology (Ricketts 2011, Täte 2011). The diagnostic value of each of these methods alone or in combination, however, is limited. Gynecological examination fails to detect subclinical endometritis (Schoon et al. 1997, LeBlanc and Causey 2009). Endometrial cytology identifies only suppurative inflammation (Schoon et al. 1997). In the case of a bacterial growth, the association of the bacterial isolate(s) with the uterine inflammation has to be confirmed (Ricketts 1981, Ricketts 2011). The uterus of the mare has been traditionally considered as sterile, a transient bacterial colonisation may occur after breeding or parturition and in older mares with abnormalities of the lower genital tract (Ricketts 1981, Tillmann et al. 1982, Ricketts 2011). Due to the results of recent studies, however, the dogma of sterility of the uterus has been questioned, and the possible presence of commensal bacteria on the endometrial surface is discussed (Ricketts and Mackintosh 1987, Ricketts 2011 , Täte 2011). For bacteriological examination of the equine endometrium, a uterine swab is routinely used (Ricketts 2011 ). Cultures may be performed by the use of an enrichment medium (Overbeck et al. 2011 , Täte 2011 ). Results of a study, however, indicated that cultures obtained from endometrial biopsies may have a higher sensitivity for the detection of bacterial causes of endometritis than swab cultures (Nielsen et al. 2005). 
The most concise method to diagnose endometritis including its subtypes is the histopathological examination of an endometrial biopsy using the diagnostic criteria described by Kenney and Doig (1986) and Schoon et al. (1992, 1997). The objective of the present study - performed on endometrial samples of 41 clinically healthy estrous warmblood mares - was to correlate bacteriological results obtained by two different culture methods (swab culture prior and after enrichment step and biopsy culture) with the histopathological diagnosis of endometritis.

\section{Materials and Methods}

\section{Animals}

Endometrial biopsies and uterine swabs were collected between June and July 2012 from 41 estrous warmblood mares at day 18 of the estrous cycle. From the majority of these mares, the age, number of foalings, date of the last foaling and a brief clinical history were known (table 1). Prior to the swab and biopsy collection, a gynecological examination was performed.

\section{Gynecological examination and sample collection}

For the gynecological examination and sample collection, mares were restrained in stocks; their tails were covered by a disposable examination glove (Krutex, Langeskov, Denmark) and tied to the neck of the mare. The vulva and perineal area were cleaned with paper towels, subsequently rinsed thoroughly with warm water and iodine solution (Degraseptin, Fa. Braun, Melsungen, Germany) and finally dried with paper towels. A sterile Polanski speculum (Hauptner) was inserted through the vagina and placed into the caudal portion of the cervix; subsequently the cervix was fixed with a forceps (Hauptner, Dietlikon-Zürich, Switzerland). Endometrial swabs were obtained using an occluded double-guarded uterine culture set (Minitüb, Tiefenbach, Germany), then a biopsy was collected. Within the uterine body, the swab remained in contact with the endometrial surface for at least 30 seconds and was rotated twice to the right and twice to the left. The endometrial biopsy was collected by the use of a sterile biopsy punch from the corpus of the uterus. The head of the biopsy punch was covered by a sterile aluminium tube that was retracted after passing the cervix. Immediately after collection, the uterine swab was transferred into a charcoal transport medium for bacteriology (method described below), and the biopsy was streaked onto agar plates for bacteriology (method described below) and subsequently fixed in $4 \%$ buffered formaldehyde for histopathology (method described below).

\section{Histopathological examination}

Endometrial biopsies were processed routinely, sectioned $(3 \mathrm{~mm})$ and stained with hemalaun-eosin. The biopsies were examined for the presence of inflammatory (endometritis, vasculitis/perivasculitis) and degenerative (endometrosis, angiosclerosis) lesions (Kenney and Doig 1986, Schoon et al. 1992, 1997) as well as glandular differentiation disorders (Schoon et al. 1997, Häfner et al. 2001). Endometritis was classified as acute suppurative, subacute suppurative and nonsuppurative (Schöniger et al. 2013). The numbers of siderocytes (Kenney and Doig 1986) and eosinophils was recorded semiquantitatively, i.e. siderocytes: minimal numbers $(\leq 1$ cell per 40x high power field [HPF]), mild numbers ( $>1 \leq 10$ cells per 40x HPF), moderate numbers $(>10 \leq 20$ cells per $40 \times \mathrm{HPF}$ ) and marked numbers (>20 per $40 \times \mathrm{HPF}$ ); eosinophils: occasional eosinophils ( $\leq 1$ cell per $40 \times \mathrm{HPF}$ ), mild numbers of eosinophils ( $>1 \leq 5$ cells per $40 \times \mathrm{HPF}$ ), and moderate numbers of eosinophils ( $>5$ cells per $40 \times \mathrm{HPF}$ ). A cellular infiltrate was diagnosed as "superficial", if the cells were restricted to the luminal epithelium and the stratum compactum.

\section{Bacteriological examination}

For bacteriological examination, two different culture methods were used, i.e. biopsy and swab culture, in regard to the latter an additional enrichment step was performed.

Biopsy culture: By the use of a sterile pair of pincers, each endometrial biopsy was streaked onto a Columbia agar plate containing $5 \%$ ovine blood (Fa. Oxoid, Wesel, Germany) and a Gassner agar plate (Fa. Oxoid, Wesel, Germany).

Swab culture: Each uterine swab was smeared onto a Columbia agar containing $5 \%$ ovine blood, a Gassner agar and a Staphylococcus/Streptococcus selective agar (Institute of Microbiology, University of Veterinary Medicine Hannover, Foundation, Germany). Subsequently, an enrichment step was performed; each swab was incubated in a nutrition bouillon (Institute of Microbiology, University of Veterinary Medicine Hannover, Foundation, Germany) over night and streaked again onto Columbia agar containing $5 \%$ ovine blood, Gassner agar and Staphylococcus/Streptococcus selective agar.

For both culture methods (swab and biopsy culture), the prepared agar plates were cultured over night under aerobic conditions at $37^{\circ} \mathrm{C}$ and read after 24 and $48 \mathrm{hrs}$. The isolated aerobic bacteria were differentiated and identified according to their morphology on culture plates and by the use of biochemical methods. The amount of isolated bacteria was evaluated semiquantitatively as mild or moderate. In regard to the swab culture, bacteria identified prior and after the enrichment step were recorded separately.

Isolated bacteria were classified as likely apathogenic bacteria and facultative pathogens according to Amtsberg and Krabisch et al. (1975), Ricketts et al. (1981), Merkt et al. (1987) and Täte (2011). The results of the bacteriological examination were reported as A or B; A-type results correlated to the culture of likely apathogenic bacteria (in the following also referred to as A-type bacteria); results were B-type, if at least one facultative pathogen was isolated (Merkt and von Lepel 1970, Merkt et al. 1987).

\section{Results}

Animals and gynecological examination

The age, number of foals, year of the last foaling and results of the gynecological examination are provided in table 1 . 
Table 1 - Mares $(n=41)$ and results of the gynecological examination / Stuten $(n=41)$ und Befunde der gynäkologischen Untersuchung

\begin{tabular}{|c|c|c|c|c|c|}
\hline No. & Age (years) & Number of foals & Year of last Parturition & Gynecological examination & Additional information \\
\hline 1 & 8 & 1 & 2009 & No alteration & - \\
\hline 2 & 13 & 7 & 2009 & No alteration & - \\
\hline 3 & 10 & 3 & 2012 & No alteration & - \\
\hline 4 & 3 & 0 & NA & No alteration & - \\
\hline 5 & 4 & 0 & NA & No alteration & - \\
\hline 6 & 21 & 1 & 2005 & No alteration & - \\
\hline 7 & 15 & 4 & 2009 & No alteration & - \\
\hline 8 & 7 & 4 & 2012 & No alteration & - \\
\hline 9 & 14 & 5 & 2010 & No alteration & - \\
\hline 10 & 9 & 6 & 2012 & $\begin{array}{l}\text { Poor closure and deviation } \\
\text { of the vulva }\end{array}$ & - \\
\hline 11 & 14 & 7 & 2011 & $\begin{array}{c}\text { Poor closure and deviation } \\
\text { of the vulva }\end{array}$ & - \\
\hline 12 & 9 & 1 & 2012 & Hematoma of the vulva after parturition & - \\
\hline 13 & 12 & 8 & 2012 & $\begin{array}{l}\text { Several endometrial cysts, poor closure } \\
\text { and deviation of the vulva }\end{array}$ & - \\
\hline 14 & 19 & 6 & 2010 & No alteration & - \\
\hline 15 & 18 & 2 & 2011 & No alteration & - \\
\hline 16 & 15 & 3 & 2009 & $\begin{array}{l}\text { Focal endometrial cyst } \\
(1,5 \times 1,5 \times 1,5 \mathrm{~cm})\end{array}$ & 3 years barren \\
\hline 17 & 12 & 4 & NK & $\begin{array}{c}\text { Focal endometrial cyst } \\
(0,9 \times 0,9 \times 0,9 \mathrm{~cm})\end{array}$ & - \\
\hline 18 & 4 & 0 & NA & NK & - \\
\hline 19 & 13 & 2 & 2004 & No alteration & - \\
\hline 20 & 14 & NK & NK & No alteration & - \\
\hline 21 & 14 & 8 & 2011 & No alteration & - \\
\hline 22 & 14 & 9 & 2012 & No alteration & - \\
\hline 23 & 19 & NK & NK & Many endometrial cysts & - \\
\hline 24 & 19 & 4 & 2008 & Several endometrial cysts & - \\
\hline 25 & 21 & 1 & 2005 & No alteration & - \\
\hline 26 & 20 & 2 & 2009 & No alteration & - \\
\hline 27 & 3 & 0 & NA & No alteration & - \\
\hline 28 & 8 & 0 & NA & No alteration & - \\
\hline 29 & 16 & 1 & 2007 & No alteration & $>2$ years barren \\
\hline 30 & 17 & 9 & 2012 & No alteration & - \\
\hline 31 & 13 & 6 & 2012 & No alteration & - \\
\hline 32 & 19 & 2 & 2009 & Several endometrial cysts & $>2$ years barren sports horse \\
\hline 33 & 8 & 0 & NA & No alteration & - \\
\hline 34 & 21 & 1 & 2005 & No alteration & - \\
\hline 35 & 20 & 1 & 2009 & No alteration & - \\
\hline 36 & 3 & 0 & NA & No alteration & - \\
\hline 37 & 9 & 0 & NA & No alteration & - \\
\hline 38 & NK & 5 & 2010 & No alteration & - \\
\hline 39 & 5 & 0 & NA & No alteration & - \\
\hline 40 & 13 & 2 & 2007 & No alteration & - \\
\hline 41 & 19 & 2 & 2009 & Several endometrial cysts & $>2$ years barren sports horse \\
\hline
\end{tabular}

NK, not known; NA, not applicable; -, no additional information 
Table 2 - Results of the histopathological examination of the endometrial biopsies (41 mares) / Ergebnisse der histopathologischen Untersuchung der Endometriumbioptate (41 Stuten)

\begin{tabular}{|c|c|c|c|c|}
\hline No. & Endometritis & Endometrosis & Angiosclerosis & Additional microsopic findings \\
\hline 1 & - & + & - & irreg diff \\
\hline 2 & - & + & ++ & - \\
\hline 3 & - & - & + & +++ siderocytes \\
\hline 4 & - & - & - & - \\
\hline 5 & + superf acute supp & - & - & $(+)$ superf eosinophils \\
\hline 6 & - & - & + & - \\
\hline 7 & - & + & ++ & irreg diff \\
\hline 8 & - & - & + & ++ siderocytes \\
\hline 9 & - & - & + & - \\
\hline 10 & + superf subacute supp & + & ++ & ++ superf siderocytes \\
\hline $11^{*}$ & - & + destructive & + & - \\
\hline 12 & + superf subacute supp & - & + & +++ siderocytes \\
\hline 13 & + superf subacute supp & + & ++ & +++ siderocytes \\
\hline 14 & - & ++ & ++ & irreg diff \\
\hline 15 & - & + & + & - \\
\hline 16 & - & ++ & ++ & - \\
\hline 17 & - & + & + & - \\
\hline 18 & - & - & + & - \\
\hline 19 & - & + & ++ & - \\
\hline 20 & - & - & ++ & + siderocytes \\
\hline 21 & - & - & ++ & - \\
\hline 22 & - & - & ++ & ++ siderocytes \\
\hline 23 & - & ++ & + & ++ siderocytes \\
\hline 24 & + superf subacute supp & ++ destructive & - & irreg diff \\
\hline 25 & + superf subacute supp & + & ++ & - \\
\hline 26 & - & ++ & + & - \\
\hline 27 & - & - & - & - \\
\hline 28 & - & - & + & - \\
\hline 29 & - & ++ & + & - \\
\hline 30 & - & + & ++ & ++ siderocytes \\
\hline 31 & + non-supp & + & ++ & ++ siderocytes \\
\hline 32 & - & + & - & - \\
\hline 33 & - & - & - & - \\
\hline 34 & - & + & ++ & $(+)$ superf eosinophils \\
\hline 35 & + superf subacute supp & ++ & ++ & - \\
\hline 36 & - & + & + & - \\
\hline 37 & + superf non-supp & - & - & - \\
\hline 38 & + non-supp & ++ & + & - \\
\hline 39 & - & + & - & ++ non-supp (peri)vasculitis \\
\hline 40 & - & + & ++ & irreg diff \\
\hline 41 & + superf subacute supp & + & + & - \\
\hline
\end{tabular}

- = absent; $(+)=$ occasional; $+=$ mild; $++=$ moderate; $+++=$ marked; superf $=$ superficial; sup $=$ suppurative; non-supp $=$ non-suppurative; irreg $=$ irregular; diff $=$ differentiation ${ }^{*}=$ biopsy with segmental absence of stratum compactum and luminal epithelium due to artefact 
Mares were between 3 and 21 years of age, with an average age of 13 years and a median age of 14 years; the age of 1 mare (No. 38) was unknown. Nine mares (Nos. 4, 5, 18, 27 , $28,33,36,37,39)$ were maiden mares; the foaling status was unknown for 2 mares (Nos. 20, 23). The remaining mares had delivered between 1 and 9 foals. Eight mares (Nos. 3, 8, 10, 12, 13, 22, 30, 31) had foaled in 2012, this had occurred 120 - 28 days prior to the sample collection for this investigation. The date of the last foaling was unknown for 3 mares (Nos. 17, 20, 23). Gynecological examination revealed no alterations in 29 mares, conformational abnormalities of the vulva in 3 mares (poor closure of the labia and lateral deviation, Nos. 10, 11, 13), a vulvar hematoma after parturition in 1 mare (No. 12), and endometrial cysts in 7 mares (Nos. 13, 16, 17, 23, 24, 32, 41); the result of the gynecological examination was not reported for 1 mare (Nos. 18). None of the mares showed clinical signs of endometritis. The time of barrenness was known for 4 mares, i.e. 3 years (No. 16) and more than 2 years (Nos. 29, 32, 41). Two of the latter mares (Nos. 32, 41 ) had been used as professional sports horses.

\section{Histopathological examination}

The results of the histopathology are summarized in table 2 . Eleven mares (Nos. 5, 10, 12, 13, 24, 25, 31, 35, 37, 38, $41)$ had endometritis; it was mild in all 11 mares and superficial in 9 mares (Nos. 5, 10, 12, 13, 24, 25, 35, 37, 41). The inflammation was acute suppurative (Fig. 1) in 1 mare (No. 5), subacute suppurative (Fig. 2) in 7 mares $(10,12,13,24,25$, 35, 41) and non-suppurative (Fig. 3) in 3 mares (Nos. 31, 37, 38). A multifocal moderate non-suppurative vasculitis and perivasculitis was diagnosed in 1 mare (No. 39).

Endometrosis was diagnosed in 26 mares. It was mild in 18 mares $(1,2,7,10,11,13,15,17,19,25,30-32,34,36$, $39-41$ ) and moderate in 8 mares (Nos. 14, 16, 23, 24, 26, $29,35,38)$. The destructive form was observed in 2 mares

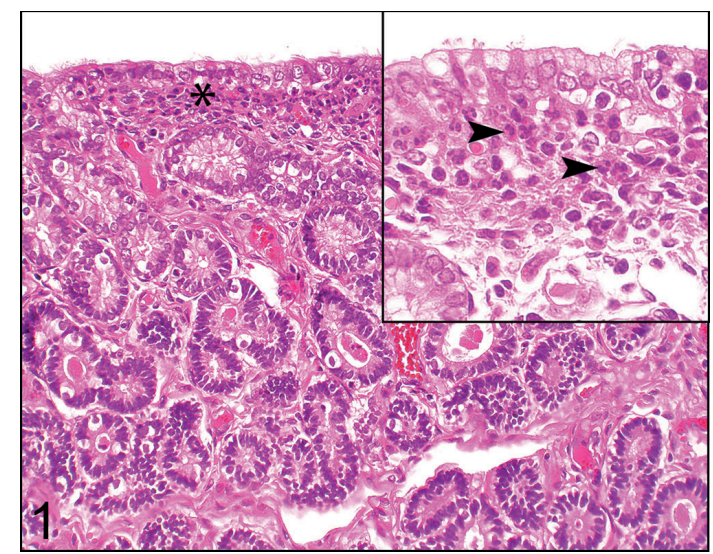

Fig. 1 - Endometrial biopsy, mare, superficial acute suppurative endometritis: The inflammatory cell infiltrate is restricted to the stratum compactum (asterisk) consistent with a superficial endometritis. In an acute suppurative endometritis, neutrophils (arrowheads) predominate. Hemalaun-eosin (HE) stain / Endometriumbioptat, Stute, oberflächliche akute eitrige Endometritis: Entzündungszellen befinden sich ausschließlich in dem Stratum compactum (Sternchen), somit handelt es sich um eine oberflächliche Endometritis. Bei einer akuten eitrigen Endometritis liegt eine Infiltration mit überwiegend neutrophilen Granulozyten (Pfeilspitzen) vor. Hemalaun-Eosin (HE) Färbung
(Nos. 11, 24) and the non-destructive form in the remaining mares. Angiosclerosis, present in 32 mares, was mild in 16 (Nos. 3, 6, 8, 9, 11, 12, 15, 17, 18, 23, 26, 28, 29, 36, 38,41 ) and moderate in 16 mares (Nos. 2, 7, 10, 13, 14, $16,19,20,21,22,25,30,31,34,35,40)$. An irregular glandular differentiation was diagnosed in 5 mares (Nos. 1, $7,14,24,40)$.

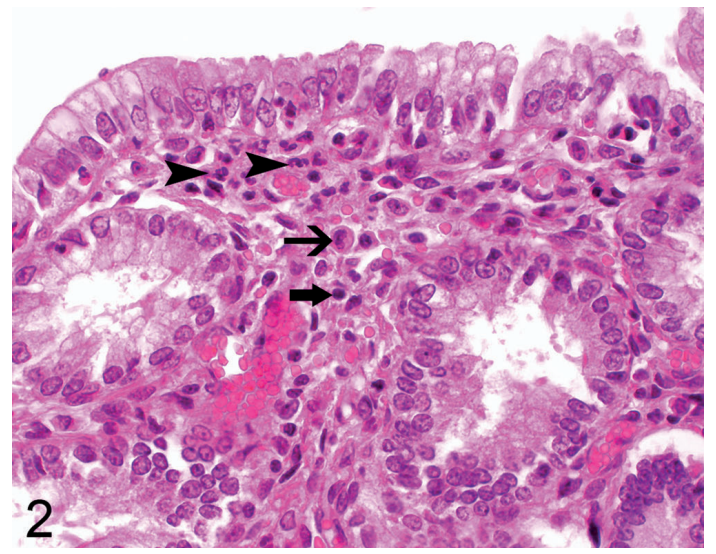

Fig. 2 - Endometrial biopsy, mare, superficial subacute suppurative endometritis: Inflammatory cells are located solely within the stratum compactum (superficial endometritis). The subacute suppurative inflammation is characterized by approximately equal numbers of neutrophils (arrowheads) and mononuclear inflammatory cells. In the present case, the latter include macrophages (thin arrow) and lymphocytes (thick arrow). HE stain / Endometriumbioptat, Stute, oberflächliche subakute eitrige Endometritis: Der Nachweis von Entzündungszellen ist auf das Stratum compactum beschränkt loberflächliche Endometritis). Bei einer subakuten eitrigen Entzündung liegt ungefähr eine gleiche Anzahl an neutrophilen Granulozyten (Pfeilspitzen) und mononukleären Entzündungszellen vor. Im vorliegenden Fall handelt es sich bei den mononukleären Entzündungszellen um Makrophagen (dünner Pfeil) und Lymphozyten (dicker Pfeil). HE Färbung

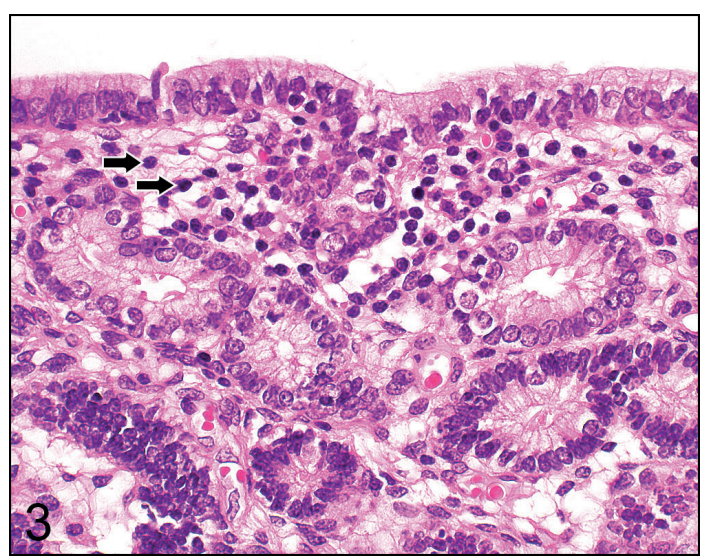

Fig. 3 - Endometrial biopsy, mare, superficial non-suppurative endometritis: Inflammatory cells are only observed within the stratum compactum (superficial endometritis). Diagnostic for a non-suppurative endometritis is an infiltration with mononuclear cells (lymphocytes, plasma cells, possibly macrophages) that exceeds the physiological amount of immune cells within the endometrial stroma. In the present case, the cellular infiltrate is composed of lymphocytes (arrows). HE stain / Endometriumbioptat, Stute, oberflächliche nicht-eitrige Endometritis: Entzündungszellen liegen nur in dem Stratum compactum vor (oberflächliche Endometritis). Kennzeichnend für eine nicht-eitrige Endometritis ist eine Infiltration mit mononukleären Zellen (Lymphozyten, Plasmazellen, möglicherweise auch Makrophagen), die zahlenmäßig die physiologische Anzahl an Immunzellen in dem endometrialen Stroma überschreitet. Im vorliegenden Fall findet sich eine Infiltration mit Lymphozyten (Pfeile). HE Färbung 
An infiltration with siderocytes was observed in 10 mares. Eight of these mares (Nos. 3, 8, 10, 12, 13, 22, 30, 31) had delivered a foal prior to the sample collection for this study. In 2 mare (Nos. 20, 23) the foaling status was unknown. Siderocytes were restricted to the stratum compactum in 1 mare (No. 10) and involved the stratum compactum and spongiosum in the remaining mares. The infiltration with siderocytes was mild in 1 mare (No. 20), moderate in 6 mares (Nos. 8, 10, 22, 23, 30, 31) and marked in 3 mares (Nos. 3, 12, 13). Infiltration with eosinophils was noted in the endometrium of 6 mares, it was always superficial; in 4 cases occasional eosinophils (Nos. 5, 8, 12, 34) and in 2 cases (Nos. 10, 13) a mild eosinophilic infiltrate was present.

\section{Bacteriological examination}

The results of the bacteriological examination are summarized in table 3. Bacteria identified by at least one method: The most frequently isolated facultative pathogenic bacteria were beta-hemolytic Streptococci (11 mares, Nos. 3, 10, 12, 15, $21,25,26,28,33,35,41)$. Additional identified facultative pathogens were Pseudomonas aeruginosa (1 mare, No. 12) and hemolytic E. coli (1 mare, No. 11). Most frequently isolated A-type bacteria were coagulase-negative Staphylococci (21 mares), E. coli (12 mares), Bacillus species (10 mares), Pseudomonas species (9 mares) and alpha-hemolytic or nonhemolytic Streptococci (7 mares).

\section{Bacterial isolates}

By the use of the biopsy culture, a mixed bacterial growth $(3$ 2 bacterial species) was obtained from 9 mares (22\%, Nos. $1,6-8,21,25,26,27,41)$, a pure bacterial growth was isolated from 10 mares (24\%, Nos. 3-5, 9-11, 14, 22, 34, $35)$ and no bacteria were cultured from the remaining 22 mares (54\%).

The swab culture prior to the enrichment step revealed a mixed bacterial culture ( ${ }^{3} 2$ bacterial species) in 7 mares (17\%; Nos. $3,9,10,11,27,31,32)$, a pure growth in 10 mares $(24 \%$, Nos. 2, 12, 15, 18, 19, 21, 25, 28, 36, 41) and no growth in 24 mares (59\%). The swab culture with enrichment step resulted in a mixed bacterial culture ( 32 bacterial species) in 21 mares (51\%), a pure growth in 12 mares (29\%, Nos. 2, $7,13,14,17,25,29,30,36-38,41)$ and no bacteria growth in 8 mares (20\%, Nos. 1, 6, 20, 22-24, 34, 39).

Facultative pathogens

Facultative pathogens were identified by biopsy culture in 3 mares (beta-hemolytic Streptococci: mares Nos. 25, 26, 41), by swab culture prior to enrichment in 4 mares (beta-hemoIytic Streptococci: mares Nos. 12, 25, 41; hemolytic E. coli: mare No. 11) and by swab culture with enrichment medium in 12 mares (beta-hemolytic Streptococci: 3, 10, 12, 15, 21 , 25, 26, 28, 33, 35, 41; hemolytic E. coli: mare No. 11; Pseudomonas aeruginosa: mare No. 12). In all mares with a positive biopsy culture of beta-hemolytic Streptococci, this bacterial agent was also detected by swab culture; in particular important for the isolation of beta-hemolytic Streptococci was the enrichment medium. The growth of beta-hemolytic Streptococci was mild in 10 cases and moderate in 1 case (No. 25), in which the moderate growth was cultured prior to the enrichment step.
Beta-hemolytic Streptococci were often cultured together with at least one A-type bacterium (swab culture with enrichment: 9/11 cases; biopsy culture: $3 / 3$ cases). A pure growth of beta-hemolytic Streptococci was only obtained in 2 mares by swab culture prior and with enrichment (Nos. 25, 41); the biopsy culture of these 2 mares revealed a mixed culture of beta-hemolytic Streptococci and A-type bacteria. In addition, beta-hemolytic Streptococci in a pure growth were isolated by swab culture prior to enrichment in 1 mare (No. 12); the swab culture after the enrichmen step revealed an additional growth of Pseudomonas aeruginosa and E. coli; the biopsy culture was negative. The hemolytic E. coli (No. 11) was cultured by swab culture together with Pseudomonas species (Atype bacteria).

Categorisation of the culture results as A or B

By biopsy culture and swab culture without enrichment medium, 38 mares (93\%) had identical categories (36 mares: A-type results; mares Nos. 25, 41 : B-type results), and 3 mares (Nos. 11, 12, 26) showed different categories.

In contrast, comparing the biopsy culture and the swab culture with enrichment medium, only 32 mares (78\%) had identical categories (27 mares: A-type results; mares Nos. 25, 26, 41: B-type results), whereas in 9 mares (Nos. 3, 10, 11, 12, $15,21,28,33,35)$ the categories differed; i.e. the biopsy culture showed A-type results, whereas the swab culture results were consistent with type $B$.

Correlation of the results of the bacteriological and histopathological examinations

Mares with endometritis $(n=11)$

Facultative pathogenic bacteria were isolated from 5 mares (beta-hemolytic Streptococci: mares Nos. 10, 25, 35, 41 ; beta-hemolytic Streptococci and Pseudomonas aeruginosa: mare No. 12). The beta-hemolytic Streptococci were identified by swab culture prior to enrichment in 3 mares (Nos. 12, $25,41)$ and with enrichment medium in the 2 remaining mares (Nos. 10, 35). Biopsy culture revealed a positive result in 2 mares (Nos. 25, 41); in these mares beta-hemolytic Streptococci were also identified by swab culture without enrichment. Endometritis was subacute suppurative in all 5 mares (Nos. 10, 12, 25, 35, 41).

In 5 mares with endometritis, only A-type bacteria were detected (by swab culture: Nos. 13, 31, 37, 38; by swab and biopsy culture: No. 5). In 1 mare (No. 24) both methods revealed no bacterial growth.

Mares without endometritis $(n=30)$

Beta-hemolytic Streptococci were also isolated from 6 mares without endometritis (Nos. 3, 15, 21, 26, 28, 33); in all 6 mares this bacterial agent was identified by swab culture after the enrichment step and in 1 of these mares (Nos. 26) also by biopsy culture. The precise histopathological evaluation of one biopsy with a positive growth of hemolytic E. coli (mare No. 11) was impaired due to the artificial segmental loss of the luminal epithelium and the stratum compactum. In the examined endometrial tissue, no inflammation was observed. 
Tab. 3 - Bacteriological culture results of the endometrial swabs and biopsies (41 mares) / Ergebnisse der bakteriologischen Untersuchungen der Endometriumtupfer und -bioptate (41 Stuten)

\begin{tabular}{|c|c|c|c|c|c|c|}
\hline No & Biopsy culture & Cat. & Swab culture prior to enrichment & Cat. & Swab culture with enrichment & Cat. \\
\hline 1 & + A-type bacteria (2) & A & No growth & A & No growth & $A$ \\
\hline 2 & No growth & A & + A-type bacterium (1) & A & + A-type bacterium (1) & A \\
\hline 3 & + A-type bacterium (1) & A & + A-type bacteria (3) & A & $\begin{array}{l}+ \text { Beta-hem Strep } \\
+ \text { A-type bacteria (3) }\end{array}$ & B \\
\hline 4 & + A-type bacterium (1) & A & No growth & A & + A-type bacteria (3) & A \\
\hline 5 & + A-type bacterium (1) & A & No growth & A & + A-type bacteria (2) & A \\
\hline 6 & + A-type bacteria (2) & A & No growth & A & No growth & A \\
\hline 7 & + A-type bacteria (2) & A & No growth & A & + A-type bacterium (1) & A \\
\hline 8 & + A-type bacteria (2) & A & No growth & A & + A-type bacteria (2) & A \\
\hline 9 & + A-type bacterium (1) & A & + A-type bacteria (2) & A & + A-type bacteria (3) & A \\
\hline 10 & + A-type bacterium (1) & A & + A-type bacteria (2) & A & $\begin{array}{l}\text { + Beta-hem Strep } \\
+ \text { A-type bacteria (2) }\end{array}$ & B \\
\hline 11 & + A-type bacterium (1) & A & $\begin{array}{l}+ \text { Hem E. coli } \\
++ \text { A-type bacterium (1) }\end{array}$ & B & $\begin{array}{l}+ \text { Hem E. coli } \\
++ \text { A-type bacterium (1) }\end{array}$ & B \\
\hline 12 & No growth & A & + Beta-hem Strep & B & $\begin{array}{l}\text { + Beta-hem Strep + Pseudomonas aeruginosa } \\
+ \text { A-type bacterium (1) }\end{array}$ & B \\
\hline 13 & No growth & A & No growth & A & + A-type bacterium (1) & A \\
\hline 14 & + A-type bacterium (1) & A & No growth & A & + A-type bacterium (1) & A \\
\hline 15 & No growth & A & + A-type bacterium (1) & A & + Beta-hem Strep $\quad+$ A-type bacterium (1) & B \\
\hline 16 & No growth & A & No growth & A & + A-type bacteria $(2)$ & A \\
\hline 17 & No growth & A & No growth & A & + A-type bacterium (1) & A \\
\hline 18 & No growth & A & ++ A-type bacterium (1) & A & + A-type bacterium (1) ++ A-type bacterium (1) & A \\
\hline 19 & No growth & A & ++ A-type bacterium (1) & A & + A-type bacterium (1) ++ A-type bacterium (1) & A \\
\hline 20 & No growth & A & No growth & A & No growth & A \\
\hline 21 & + A-type bacteria (2) & A & + A-type bacterium (1) & A & + Beta-hem Strep + A-type bacterium (1) & B \\
\hline 22 & + A-type bacterium (1) & A & No growth & A & No growth & A \\
\hline 23 & No growth & A & No growth & A & No growth & A \\
\hline 24 & No growth & A & No growth & A & No growth & A \\
\hline 25 & $\begin{array}{l}++ \text { Beta-hem Strep } \\
+ \text { A-type bacterium (1) }\end{array}$ & B & ++ Beta-hem Strep & B & ++ Beta-hem Strep & B \\
\hline 26 & $\begin{array}{l}+ \text { Beta-hem Strep } \\
+ \text { A-type bacteria (4) }\end{array}$ & B & No growth & A & + Beta-hem Strep + A-type bacteria (2) & B \\
\hline 27 & + A-type bacteria (3) & A & ++ A-type bacteria $(2)$ & A & ++ A-type bacteria (2) & A \\
\hline 28 & No growth & A & + A-type bacterium (1) & A & + Beta-hem Strep + A-type bacteria (3) & B \\
\hline 29 & No growth & A & No growth & A & + A-type bacterium (1) & A \\
\hline 30 & No growth & A & No growth & A & + A-type bacterium (1) & A \\
\hline 31 & No growth & A & A-type bacteria (3) & A & + A-type bacteria (4) & A \\
\hline 32 & No growth & A & A-type bacteria (2) & A & + A-type bacteria (3) & A \\
\hline 33 & No growth & A & No growth & A & + Beta-hem Strep $\quad+$ A-type bacterium (1) & B \\
\hline 34 & + A-type bacterium (1) & A & No growth & A & No growth & A \\
\hline 35 & + A-type bacterium (1) & A & No growth & A & + Beta-hem Strep & B \\
\hline 36 & No growth & A & + A-type bacterium (1) & A & + A-type bacterium (1) & A \\
\hline 37 & No growth & A & No growth & A & + A-type bacterium (1) & A \\
\hline 38 & No growth & A & No growth & $A$ & + A-type bacterium (1) & A \\
\hline 39 & No growth & A & No growth & A & No growth & A \\
\hline 40 & No growth & A & No growth & $A$ & + A-type bacteria (2) & A \\
\hline 41 & $\begin{array}{l}+ \text { Beta-hem Strep } \\
+ \text { A-type bacteria (2) }\end{array}$ & B & + Beta-hem Strep & B & + Beta-hem Strep & B \\
\hline
\end{tabular}

+, mild; ++, moderate, hem, hemolytic, Strep, Streptococci; Cat. A, Category A (likely apathogenic bacteria);

Cat B, Category B (isolation of at least one facultative pathogen); A-type bacterium, likely apathogenic bacterial isolate;

A-type bacterium (1), one A-type bacterium was isolated; A-type bacteria (2), (3), (4), two, three or four A-type bacteria were isolated 
Mares with predisposing conditions

In 2012, 8 mares had foaled 120-28 days prior to the biopsy collection (Nos. 3, 8, 10, 12, 13, 22, 30, 31); 3 of these mares (Nos. 10, 12, 13) and 1 additional mare (No. 11) showed lesions of the vulva. Mares Nos. 10 and 12 had a subacute suppurative endometritis with isolation of betahemolytic Streptococci (Nos. 10, 12), Pseudomonas aeruginosa (No. 12) and A-type bacteria (Nos. 10, 12). Only A-type bacteria were cultured from the endometrium of 2 mares that showed a subacute suppurative (No. 13) or a non-suppurative endometritis (No. 31). Facultative pathogens were also detected in endometrium of 1 mare without evidence of endometritis (Nos. 3) and 1 mare (No. 11) with a biopsy altered by artefact that impaired segmentally the concise histopathological evaluation of the superficial aspects of the endometrium.

\section{Discussion}

\section{Histopathological examination}

In the present study on the endometrium of 41 mares, the results of two different bacterial culture methods were correlated with the histopathological detection of inflammation. The histopathological diagnosis of endometritis was performed according to Kenney and Doig (1986) and Schoon et al. (1992 and 1997). This method has to be regarded as the gold standard for the diagnosis of endometritis, since it will detect with certainty all subtypes of endometritis including suppurative and non-suppurative forms. The accurate classification of endometritis has prognostic and therapeutic significance. For example, the treatment of a suppurative inflammation is commonly curative, whereas a non-suppurative endometritis is often only partially reversible (Schoon et al. 1997). By the microscopic evaluation of an endometrial biopsy, the additional presence of degenerative alterations (endometrosis, angiosclerosis) and glandular differentiation disorders can be detected resulting in a complete assessment of all factors that can contribute to subfertility (Kenney and Doig 1986, Schoon et al. 1992 and 1997). In some studies, the histopathological diagnosis of endometritis was based solely on counting neutrophils in tissue sections (Nielsen 2005, Overbeck et al. 2011 , Nielsen et al. 2012). This examination protocol, however, would fail to detect a non-suppurative endometritis as an important cause of reduced fertility; it can be observed in approximately $15 \%$ of barren mares (Schoon et al. 1997).

The presence of neutrophils in the equine endometrium is influenced by the stage of the cycle. During proestrus and estrus, scattered neutrophils may be observed within the stratum compactum and the luminal epithelium, whereas the presence of any numbers of neutrophils during the remaining stages of the cycle is consistent with an inflammatory infiltrate (Brunkkhorst et al. 1991). All biopsies of the present study were collected during estrus, therefore occasional neutrophils within the superficial endometrium were regarded as within normal limits.

\section{Bacteriological examination}

Bacteria that can be isolated from uterine fluid and/or endometrial tissue include obligate pathogens (veneral disease organisms), facultative pathogenic bacteria and likely apathogenic bacteria (Ricketts 1981, Ricketts 2011, Täte 2011). In the present study, identified facultative pathogens were beta-hemolytic Streptococci, Pseudomonas aeruginosa and hemolytic E. coli (Ricketts 1981). Similar to other studies, 1) the most commonly isolated facultative pathogenic bacteria were beta-hemolytic Streptococci (Flüge et al. 1972, Merkt et al. 1987, Nielsen 2005, Ricketts 2011 ), 2) facultative pathogens were isolated from horses with and without evidence of endometritis (Kenney 1978, Ricketts 1981, Ricketts 2011, Täte 2011) and 3) some horses with endometritis yielded a negative culture result (Ricketts 1981). Therefore, this study showed - as also observed in previous investigations - that the bacteriological culture cannot be used as the only method for the diagnosis of endometritis (Kenney 1978, Ricketts 1981, Ricketts 2011). The significance of a bacterial isolate should be evaluated under consideration of clinical findings and the results of a complete histopathological evaluation of an endometrial biopsy (Kenney 1978, Kenney and Doig 1986, Schoon et al. 1997). Factors (previous parturition and/or vulvar lesions) predisposing to a bacterial entry into the uterine lumen (Tillmann et al. 1982 ) were known for 9 mares. A uterine bacterial entry from parturition should be cleared spontaneously within 1 week (Merkt and von Lepel 1970), but may also exacerbate a pre-existing chronic endometritis (Hurtgen 2006). In 2 mares with vulvar lesions and a recent parturition, endometritis with a positive growth of beta-hemolytic Streptococci was detected; thus a bacterial endometritis associated with predisposing factors (Tillmann et al. 1982, Bader and Merkt 1992) appears most likely.

The sample collection technique of this study should have prevented a bacterial contamination as much as possible; a speculum (Waelchli et al. 1992, Täte 2011 ), double-guarded uterine swabs (Blanchard et al. 1981 a, Täte 2011) and a sterile aluminium cover for the head of the biopsy punch were used. By the application of marker bacteria, Waelchli et al. (1992) showed, however, that using a speculum (instead of the manual sampling technique) resulted in fewer contaminants, but failed to prevent contamination completely. Similarly, in this study, small numbers of bacteria were isolated from several mares (including maiden mares and mares that had delivered foals) without endometritis. Possible explanation to consider are that 1) a contamination of samples may still have occurred, and/or 2) at least some of these mares may have had a (transient) bacterial colonisation of the endometrium, not associated with inflammation (Ricketts 1981, Hinrichs et al. 1988, Ricketts 2011, Täte 2011).

\section{Bacterial culture methods}

The biopsy culture and the swab culture without enrichment medium showed a similar sensitivity for the detection of facultative pathogens, but differed in the numbers and types of isolated A-type bacteria. The latter may be related to contamination (Blanchard et al. 1981 b, Waelchli et al. 1992) or local differences of a possible (transient) bacterial colonisation of the endometrium (Ricketts 1981, Hinrichs et al. 1988, Ricketts 2011, Täte 2011). Areas sampled by a swab and a biopsy differ slightly; the biopsy is collected from more cranial aspects of the uterus, whereas the swab is obtained from the endometrium immediately cranial to the cervix (LeBlanc 
2010, Coccia et al. 2012). The present study did not confirm the observation of Nielsen (2005), that cultures obtained from an endometrial biopsy have a higher sensitivity for the detection of bacterial causes of endometritis than swab cultures. Both studies, however, differed in regard to the sample collection, interpretation of bacteriological results and the histopathological method to confirm endometritis.

The enrichment step was in particular important for the identification of facultative pathogenic bacteria; but also resulted in the growth of additional A-type bacteria. This suggests that the type of sample (guarded swab or endometrial biopsy) has less significant influence on the isolation of facultative pathogens than the use of enrichment medium.

Thus, for a complete diagnostic workup, it would be advis-able to perform the bacteriological examination by the use of enrichment medium, even if this will require additional culture time. In this investigation, only the swab was incubated in enrichment medium, since the endometrial biopsy was need-ed for the histopathological examination. Endometrial tissue, however, can also be placed in enrichment medium (personal communication Professor Wittenbrink, Institute of Veterinary Bacteriology, Vetsuisse Faculty, University of Zurich, Zurich, Switzerland), in this case sufficient endometrial tissue for both investigations (histopathology and bacteriology) has to be collected.

Correlation of the results of the bacteriological and histopathological examinations

Endometritis in association with the isolation of facultative pathogenic bacteria: An association between endometritis and a bacterial isolate is considered as very likely, if the bacterial isolate is retrieved as a pure growth and/or in higher numbers (Ricketts 1981).

Therefore, the isolated beta-hemolytic Streptococci were regarded as the likely cause of the endometritis in mares Nos. 25 and 41 . They were detected by biopsy and swab culture and were isolated as pure-growth by at least one method; in addition, they showed a moderate growth in one of these mares (No. 25). In the remaining three cases with a positive growth of beta-hemolytic Streptococci only by swab culture, the significance of the isolate as cause of the endometritis has to be substantiated by ruling out other causes of endometritis. Beta-hemolytic Streptococci retrieved from the endometrium of mares usually belong to the Lancefield serogroup C, most frequently Streptococcus equi subspecies zooepidemicus is identified (Wittenbrink et al. 2008). Molecular studies suggest that Streptococcus equi subspecies zooepidemicus can persist in the equine endometrium after antibiotic treatment (Wittenbrink et al. 2008) and that genetically distinct subtypes of this bacterial agent are associated with equine endometritis (Rasmussen et al. 2013). The latter finding challenges the assumption that identical bacterial populations are found on the external genital area and within the uterus (Rasmussen et al. 2013).

Endometritis in association with no isolation of (facultative) pathogenic bacteria: In 6 mares with histological confirmation of endometritis (Nos. 5, 13, 24, 31, 37, 38), no (facultative) pathogenic bacteria were isolated by swab and biopsy culture. This could be related to an unequal distribution of bacteria on the endometrial surface (LeBlanc and Causey 2009), previous (unreported) antibiotic treatment, the presence of infectious agents that cannot be identified with the applied methods (Rikketts 1981), an already established clear-ance of the causative bacterial agent (Kenney 1978) or a sterile inflammation (Rikketts 1981, Kenney and Doig 1986). Numerous bacteria are not culturable on routinely used laboratory media due to complex nutritional requirements (Lewis 2007). With the applied methods, anaerobic bacteria (Ricketts and Mackintosh 1987) or Chlamydia psittaci (Hülsey 2011), as possible causes of equine endometritis, would remain undetected. Endometritis may occasionally be evoked by A-type bacteria (Amtsberg and Krabisch 1975). Histologic sections showed no evidence for the presence of yeast or fungi. A sterile endometritis may develop due to the persistence of antigens (Schoon et al. 1992), a hypergic-allergic reaction (Schoon et al. 1992) or the exposure to a local irritating substance.

Isolation of (facultative) pathogenic bacteria in the absence of endometritis: The isolation of (facultative) pathogenic bacteria from mares without endometritis has been described in the literature as well (Ricketts 1981, Tillmann et al. 1982). Poss-ible explanations are a bacterial contamination (Ricketts 1981), a (temporary) bacterial colonisation of the endometrium without induction of an inflammatory response (Ricketts 2011) or a peracute infection. In addition, whereas most of the betahemolytic Streptococci are potential pathogens, a few subtypes of this bacterial class are regarded as faecal contaminants (Atype bacteria) and thus would not evoke inflammation if present in small numbers (Amtsberg and Krabisch 1975).

Comparison of the results of this study with previous investigations

A comparison of this study with other investigations is impaired due to differences in one or several of the following methods, i.e. sample collection, bacterial culture, interpretation of results and applied tests to confirm endometritis. Uterine swabs or endometrial biopsies can be collected under manual control (Täte 2011, Cocchia et al. 2012, Overbeck et al. 2012) and/or by the use of a speculum (Merkt et al. 1987, Täte 2011 ). Most frequently guarded (Nielsen 2005, Cocchia et al. 2012) or double guarded swabs (Hinrichs ef al. 1988, Täte 2011) were used. The bacterial culture was performed without enrichment medium (Hinrichs et al. 1988, Nielsen 2005, Nielsen et al. 2012) or by the addition of an enrichment step (Amtsberg and Krabisch 1975, Hülsey 2001 , Overbeck et al. 2012). The interpretation of the microbiological results varied between studies; e. g. it was solely recorded if potential pathogenic bacteria were detected (Blanchard et al. 1981b) or the isolated facultative pathogenic bacteria were subclassified and analyzed semiquantitatively (Purswell et al. 1989, Albihn et al. 2003). In some studies, isolated facultative pathogens were only considered as clinical relevant, if they had grown in a monoculture (Nielsen 2005) or if a moderate to marked growth was observed (Purswell et al. 1989). Cultures of an endometrial biopsy may be performed directly by its inoculation on culture plates (Nielsen 2005) or indirectly by sampling its surface with a uterine swab (Overbeck et al. 2011). For confirmation of endometritis, assessment of neutrophils in endometrial tissues (Nielsen 2005, Overbeck et al. 201 1) or cytological smears (Riddle et 
al. 2007) or a complete histopathological evaluation (Jäger et al. 2011 ) were used.

\section{Additional histopathological findings}

Siderocytes, i.e. haemosiderin-laden macrophages, indicative of previous hemorrhage (Kenney 1978, Schoon et al. 1992) were detected in all mares that had foaled in 2012 and in 2 mares with an unknown foaling status. Small numbers of eosinophils within the equine endometrium - as observed in 6 mares of this study - are considered as within physiological limits (Schoon et al. 1992). An irregular differentiation of endometrial glands during the breeding season suggests an ovarian disorder, but may also occur idiopathic (Schoon and Schoon 2003). All mares of this study with a moderate endometrosis, an age related glandular alteration (Schoon et al. 1997), were ${ }^{3} 15$ years of age (the age of mare No. 38 was unknown). Angiosclerosis is a degenerative vascular lesion associated with increased age and parity (Schoon et al. 1997); a mild form of this lesion was observed only in 3 maiden mares. One mare showed a non-suppurative vasculitis and perivasculitis, a finding with commonly undetermined aetiology (Schoon et al. 1997).

\section{Conclusion}

The correct diagnosis of bacterial endometritis (in particular subclinical forms) is likely facilitated by 1) the histopathological examination of an endometrial biopsy according to Kenney and Doig (1986) and Schoon et al. (1992, 1997) that allows the identification of all subtypes of endometritis, and 2) bacterial culture using an enrichment medium. To gain further insights into the bacterial flora of the healthy and diseased equine endometrium and the pathogenesis of bacterial endometritis, molecular techniques may be applied for bacterial subtyping and identification of virulence factors (Wittenbrink et al. 2008), and in-situ hybridisation could reveal the location of bacterial agents within the equine endometrium (Jäger et al. 2011 ). These investigations would be an important prerequisite to establish additional treatment options.

\section{Acknowledgment}

The authors thank the histology laboratory, Institute of Veterinary Pathology, University of Leipzig for excellent technical support.

\section{References}

Albihn A., Båverud V., Magnusson U. (2003) Uterine microbiology and antimicrobial susceptibility in isolated bacteria from mares with fertility problems. Acta Vet. Scand. 44, 121-129

Amtsberg G., Krabisch P. (1982) Ergebnisse der bakteriologischen Zervixtupferuntersuchung von Warmblutstuten in den Jahren 1969-1973. Dtsch. tierärztl. Wschr. 82, 97-136

Bader H., Merkt H. (1992) Mikrobiell bedingte Fruchtbarkeitsstörungen bei der Stute. Tierärztl. Umschau 47, 67-72

Blanchard T. L., Garcia M. C., Hurtgen J. P., Kenney R. M. (1981a) Comparison of two techniques for obtaining endometrial bacteriologic cultures in the mare. Theriogenology 16, 85-93
Blanchard T. L., Cummings M. R., Garcia M. C., Hurtgen J. P., Kenney R. M. (1986b) Comparison between two techniques for endometrial swab culture and between biopsy and culture in barren mares. Theriogenology 16, 541-552

Brunckhorst D., Schoon H.-A., Bader H., Sieme H. (1991) Morphologische enzym- und immunhistochemische Charakteristika des endometrialen Zyklus bei der Stute. Fertilität 7, 44-51

Causey R. C. (2006) Making sense of equine uterine infections: the many faces of physical clearance. Vet J. 172, 405-421

Cocchia N., Paciello O., Auletta L., Uccello V., Silvestro L., Mallardo K., Paraggio G., Pasolini M. P. (2012) Camparison of the cytobrush, cottonswab, and low-volume uterine flush techniques to evaluate endometrial cytology for diagnosing endometritis in chronically infertile mares. Theriogenology 77, 89-98

Flüge A., Krüger A., Scherbarth R. (1972) Zuchthygienische Überwachung der hannoverschen Warmblutzucht. Dtsch. Tierärztl. Wschr. 79, 389-412

Häfner I., Schoon H.-A., Schoon D., Aupperle H. (2001) Glanduläre Differenzierungsstörungen im Endometrium der Stute - Lichtmikroskopische und immunhistologische Untersuchungen. Pferdeheilkunde 17, 103-110

Hinrichs K., Cummings M. R., Sertich P. L., Kenney R. M. (1988) Clinical significance of aerobic bacterial flora of the uterus, vagina, vestibule, and clitoral fossa of clinically normal mares. J. Am. Vet. Med. Assoc. 193, 72-75

Hülsey A. W. (2001) Chlamydia psittaci im equine Endometrium. Diss. med. vet. University Leipzig, Germany

Hurtgen J. P. (2006) Pathogenesis and treatment of endometritis in the mare: a review. Theriogenology 66, 560-566

Jäger K., Gräfe H., Klug E., Schoon D., Schoon H.-A. (2011) In situHybridisierung an Endometriumbioptaten der Pferdestute: ein diagnostischer Ansatz bakteriell bedingter Endometritiden? Pferdeheilkunde 27, 214-219

Kenney R. M. (1978) Cyclic and pathologic changes of the mare endometrium as detected by biopsy, with a note on early embryonic death. J. Am. Vet. Med. Assoc. 172, 241-262

Kenney R. M., Doig P. A. (1986) Equine endometrial biopsy. In: Current therapy in theriogenology, Morrow D.A. Editor, 2nd Ed., WB Saunders, Philadelphia, USA, pp. 723-729

LeBlanc M. M., Causey R. C. (2009) Clinical and subclinical endometritis in the mare: both threats to fertility. Reprod. Dom. Anim. 44 Suppl 3, 10-22

LeBlanc M. M. (2010) Advances in the diagnosis and treatment of chronic infectious and post-mating-induced endometritis in the mare. Reprod. Dom. Anim. 45, 21-27

Lewis K. (2007) Persister cells, dormancy and infectious disease. Nat. Rev. Microbiol. 5, 48-56

Merkt H., Lepel J. Frhr. von (1970) Die Entnahme von Proben für die bakteriologische Untersuchung des Genitalsekretes der Stute, ihre Beurteilung sowie Behandlungahinweise. Dtsch. tierärztl. Wschr. 77, 489-528

Merkt H., Wöckener A., Heilkenbrinker T., Zemke M., Wittenbrink M. M., Bisping W. (1987) Mikrobiologische Untersuchungen in der Stutengynäkologie. Prakt. Tierarzł 3, 5-12

Nielsen J. M. (2005) Endometritis in the mare: a diagnostic study comparing cultures from swab and biopsy. Theriogenology 64, 510-518

Nielsen J. M., Nielsen F. H., Petersen M. R. (2012) Diagnosis of equine endometritis - microbiology, cytology and histology of endometrial biopsies and the correlation to fertility. Pferdeheilkunde 28, 8-13

Overbeck W., Witte T. S., Heuwieser W. (2011) Comparison of three diagnostic methods to identify subclinical endometritis in the mare. Theriogenology 75, 1311-1318

Purswell B. J., Ley W. B., Sriranganathan N., Bowen J. M. (1989) Aerobic and anaerobic bacterial flora in the postpartum mare. J. Eq. Vet. Sc. 9, 141-144

Rasmussen C. D., Haugaard M. M., Petersen M. R., Nielsen J. M., Pedersen H. G., Bojesen A. M. (2013) Streptococcus equi subsp. zooepidemicus isolates from equine infectious endometritis belong to a distinct genetic group. Vet. Res. 44, 26

Ricketts S. W. (1981) Bacteriological examinations of the mare s cervix: techniques and interpretation of results. Vet. Rec. 108, 46-51 
Ricketts S. W., Mackintosh M. E. (1987) Role of anaerobic bacteria in equine endometritis. J. Reprod. Fertil. Suppl. 35, 343-351

Ricketts S. W. (2011) Uterine and clitoral cultures. In: Equine reproduction, McKinnin A. O., Squires E. L., Vaala W. E. and Varner D. D., eds; Wiley-Blackwell, Chichester, West Sussex, PO19 8SQ, UK, 2nd ed., Vol 2, pp. 1963-1978

Riddle W. T., LeBlanc M. M., Stromberg A. J. (2007) Relationships between uterine culture, cytology and pregnancy rates in a Thoroughbred practice. Theriogenology 68, 395-402

Schöniger S., Gräfe H., Schoon H.-A. (2013) Beta-defensin is a component of the endometrial immune defence in the mare. Pferdeheilkunde 29, 335-346

Schoon H.-A., Schoon D., Klug E. (1992) Uterusbiopsien als Hilfsmittel für Diagnose und Prognose von Fertilitätsstörungen der Stute. Pferdeheilkunde 8, 355-362

Schoon H.-A., Schoon D., Klug E. (1997) Die Endometriumbiopsie bei der Stute im klinisch-gynäkologischen Kontext. Pferdeheilkunde $13,453-464$
Schoon H.-A., Schoon D. (2003) The category I mare (Kenney and Doig 1986): expected foaling rate $80-90 \%$ - fact or fiction? Pferdeheilkunde 19, 698-701

Täte M. (2011) Kulturelle sowie 16S rDNA basierte Untersuchungen der aeroben und anaeroben Keimflora des equinen Uterus. [Dissertation med. vet]. Hannover, Unit of Reproductive Medicine of Clinics, University of Veterinary Medicine Hannover, Foundation

Tillmann H., Meinecke B., Weiß R. (1982) Genitalinfektionen beim Pferd. Tierärtl. Praxis 10, 91-114

Waelchli R. O., Corboz L., Doebeli M. (1992) Streptomycin-resistant Escherichia coli as a marker of vulvovestibular contamination of endometrial culture swabs in the mare. Can. J. Vet. Res. 56, 308-312

Wittenbrink M. M., Hoelzle K., Hoelzle L. E. (2008) What s new in bacteriology of the mare s genital tract. Pferdeheilkunde 24, 5355

Woolcock J. B. (1980) Equine bacterial endometritis. Diagnosis, interpretation, and treatment. Vet. Clin. North Am. Large Anim. Pract. 2, 241-251

Gesundes und erkranktes Stuten-Endometrium: Vergleich von histopathologischen Befunden und den Ergebnissen zweier unterschiedlicher bakteriologischer Untersuch-ungsmethoden (Uterustupfer und Endometriumbioptat)

Endometritis ist eine wichtige Ursache von Subfertilität bei Stuten und kann deshalb hohe finanzielle Verluste für die Pferdezucht bedeuten. Entzündliche Erkrankungen des equinen Endometriums werden häufig durch eine bakterielle Infektion hervorgerufen. In dieser Studie wurden Endometriumtupfer und -bioptate von 41 Stuten untersucht; für jede dieser Stuten sollten die Ergebnisse zweier unterschiedlicher bakteriologischer Untersuchungsmethoden miteinander verglichen werden und mit den histopathologischen Befunden korreliert werden. Für die bakteriologische Untersuchung wurden Endometriumtupfer mit einem Anreicherungsverfahren unter aeroben Bedingungen kultiviert; weiterhin erfolgte unter aeroben Bedingungen eine Kultivierung von Endometriumbioptaten. Bei keiner der 41 Stuten lagen bei der gynaekologischen Untersuchung klinische Hinweise auf eine Endometritis vor. Mittels der histopathologischen Untersuchung eines Endometriumbioptates wurde bei 11 der 41 Stuten eine Endometritis nachgewiesen; diese war bei allen Stuten geringgradig und bei 9 Stuten oberflächlich. Eine akute eitrige Entzündung lag bei 1 Stute vor, eine subakute eitrige Endometritis bei 7 Stuten und eine nicht-eitrige Entzündung bei 3 Stuten. Bei der bakteriologischen Untersuchung wurden die folgenden fakultativ pathogenen Bakterien nachgewiesen: betahämolysierende Streptokokken (11 von 41 Stuten, $27 \%$ ), Pseudomonas aeruginosa (1 Stute) and hämolysierende E. coli (1 Stute). Bei der Kultivierung von Endometriumtupfern unter Verwendung des Anreicherungsverfahrens wurden häufiger fakultativ pathogene Bakterien (12 Stuten) nachgewiesen als bei der Kultivierung der Endometriumbioptate bzw. der Auswertung der Befunde von Endometriumtupfern vor Anwendung des Anreicherungsverfahrens. Die bakteriologische Untersuchung von Endometriumtupfern nach Anwendung des Anreicherungsverfahrens ergab auch die höchste Anzahl an bakteriellen Mischkulturen (51 \%). Die Ergebnisse der bakteriologischen Untersuchungen wurden in die Kategorien A (höchstwahrscheinlich apathogene Flora) und B (Isolierung mindestens eines fakultativ pathogenen Keims) eingeteilt. Ein Vergleich der Kategorien von Endometriumbioptaten und Endometriumtupfern vor der Anreicherung ergab eine $93 \%$ Übereinstimmung, während die Kategorien von Endometriumbioptaten und Endometriumtupfern nach Anreicherung nur eine $78 \%$ Übereinstimmung aufwiesen. Die Korrelation von bakteriologischen und histopathologischen Befunden ergab das Vorliegen von fakultativ pathogenen Bakterien bei 5 der 11 Stuten mit einer Endometritis; beta-hämolysierende Streptokokken wurden auch von 6 Stuten ohne Endometritis kultiviert. Bei der Stute mit dem Nachweis von hämolysierenden E. coli konnte aufgrund des Vorliegens von Gewebsartefakten keine ausführliche Beurteilung des Endometriumbioptates erfolgen. Die Ergebnisse dieser Untersuchung zeigen, dass bakteriologische Befunde unter Berücksichtigung der verwendeten Kultivierungsmethoden interpretiert werden sollten und ein Anreicherungsmedium zum Nachweis fakultativ pathogener Bakterien von Vorteil ist. Weiterhin sollten die Ergebnisse der bakteriologischen Untersuchungen zusammen mit den histopathologischen Befunden ausgewertet werden. Eine vollständige histologische Untersuchung (anstelle einer zytologischen Untersuchung) ist als die Methode der Wahl für die Diagnose einer Endometritis anzusehen, weil dadurch alle histopathologischen Formen der Endometritis festgestellt werden können, und diese genaue Einteilung der Endometritis eine prognostische und therapeutische Bedeutung hat. Um über die Notwendigkeit einer antibiotischen Behandlung zu entscheiden, ist eine vergleichende Beurteilung bakteriologischer und histopathologischer Befunde notwendig.

Schlüsselwörter: Endometriumbioptat / mikrobiologische Untersuchung von Endometriumproben / Endometritis / Histopathologie / Stute / Reproduktion 